\title{
Optimization of Soft Body Armor with Laminates of Carbon-aramid Fiber and Polyester Fiber Using the Taguchi Method
}

\author{
Hari Purnomo*, Wahyu Ismail Kurnia, Farham Haji Muhammad Saleh, and Alex Kisanjani \\ Faculty of Industrial Technology, Department of Industrial Engineering, Universitas Islam Indonesia, \\ Jl. Kaliurang km 14.5, Sleman, Yogyakarta 55584, Indonesia
}

\begin{abstract}
Body armor is a vital instrument for Tentara Nasional Indonesia-Indonesian National Armed Forces (TNI) and Polisi Republik Indonesia-Indonesian National Police (POLRI) to protect themselves from any projectile penetration and the spread of explosive material. One type of body armor is soft body armor, commonly used for handling community riots. The forming material of soft body armor should be strong and flexible. For that, selecting appropriate materials to optimize their ability is necessary. This research aims to develop soft body armor with carbonaramid and polyester laminate as materials using a quasi-static impact test. The method used was the Taguchi experiment, the advantage of which is its ability to optimize the desired quality characteristics based on the best factor. The results showed that the optimal combination of polyester and carbon-aramid composite materials showed a median result from the quasi-static impact test of $61259.91 \mathrm{~N}$ with the optimum compositions of factor D level 1, factor A level 2, factor B level 1, factor E level 2, factor C level 2, factor F level 1, and factor G level 2.
\end{abstract}

Keywords: protective clothing, quasi-static, synthetic fiber materials, the pattern of lamination.

\section{Introduction}

The development of body armor is indispensable, because body armor is an important equipment for Tentara Nasional Indonesia-Indonesian National Armed Forces (TNI) and Polisi Republik Indonesia-Indonesian National Police (POLRI) to protect themselves from sharp weapons, projectile penetration, and the danger of explosive material. In addition, it can reduce the direct impact of projectiles to the body. Based on its type, body armor is divided into two kinds: soft and hard body armor.

Various material compositions of soft body armor have been designed, including polyester fiber by Qiushi et al. [1], ultra-high-molecular-weight polyethylene fiber by Phoenix et al. [2], and aramid fiber by Abtew et al., Nilakantan et al., and Struszczyk et al. [3-5]. These synthetic fiber materials are widely used as base materials for soft body armor because of their flexibility. In addition, synthetic fibers have good mechanical traits,

*Corresponding author: haripurnomo@uii.ac.id 
particularly aramid and polyester, as outlined by Hani et al. [6] and Yi et al. [7]. Aramid fiber's melting point is $\pm 300{ }^{\circ} \mathrm{C}$, while that of polyester fiber is $\pm 260{ }^{\circ} \mathrm{C}$ [8]. Both types of fibers have an endurance strength that is almost equivalent to Kevlar fiber. There are many studies related to these two types of fiber, one of which was conducted by Struszczyk et al. [5], who used aramid fiber as a soft body armor material in accordance with International Mine Action Standards (IMAS) and European standards. Two other studies were conducted by Abtew et al. [3] and Laha et al. [9] on the effect of aramid fiber as a soft body armor material. Furthermore, Zubaidi et al. [10] used polyester fiber as a soft body armor material that can reach level II according to the National Institute of Justice (NIJ) standard. There was also a study conducted by Zhou et al. [7] using polyester fibers to reduce the ballistic impact on soft body armor.

Innovation in the construction of materials is crucial to increase the strength of body armor, and that matter becomes such effective and efficient approach by Yanfei and Xiaogang [11]. Yilmazcoban and Doner [12] combined carbon fiber, aluminum, aramid, and wood coating to get maximum results for the body armor material. Meanwhile, Dimeski et al. [13] used a combination of polyethylene composites, and Qianyun et al. [14] combined Kevlar fabrics by inserting shear stiffening gel (STG) and shear thickening fluid (STF) to improve the collision resistance of the body armor material.

Based on the description above, the researchers are interested in developing soft body armor using carbon-aramid fiber and polyester fiber laminate as the base material. This research is the development of research by Purnomo et al. [15], who use carbon-aramid fiber as a base material for soft body armor. The method used in this study was the Taguchi experiment. The advantage of the Taguchi method is its ability to optimize the conditions of the performance characteristics needed based on the best factor [16-18]. In addition, the ability of the soft body armor was examined using a quasi-static impact test equalized with a $9 \mathrm{~mm}$ caliber projectile before a ballistic test. This research is a preliminary study that can be used as a base for further research on synthetic fiber materials to generate inexpensive and easily produced body armor.

\section{Research and method}

\subsection{Materials and tools}

The materials used in this study were: (i) carbon-aramid fiber type A1500-T, (ii) polyester fiber type 1170 (1050), and (iii) nylon thread sizes 40/2 and 20/2 to bind the carbon-aramid and polyester fibrous fabrics together. Meanwhile, the tools used in this research were: (i) a universal testing machine (UTM) type Hung Ta 9501 with ISO/IEC 17025, (ii) lamination clamps with 12 bolt compositions as a soft body armor material holder during the quasistatic impact test, and (iii) an aid in the form of a $9 \mathrm{~mm}$ caliber bullet like projectile.

\subsection{Experiment design}

The design used in this research was the Taguchi method. The factor and level were determined based on $\mathrm{L}_{8} 2^{7}$ in an orthogonal array value by $\mathrm{Yu}$ et al. [18] to generate the optimum experiment design by estimating the impact of eight factors, two levels, and three quasi-static impact replication tests. The basic material of the soft body armor is laminate consisting of carbon-aramid fibrous fabrics and polyester fibrous fabrics, where the amount of laminations is seven and 10 per material. There are two types of woven carbon-aramid and polyester fibers: plain and twill. 
Each sheet of carbon-aramid and polyester fibrous fabric as a lamination constituent was cut to $20 \mathrm{~cm} \times 20 \mathrm{~cm}$ in a parallel direction, and each was rotated $90^{\circ}$ from a position in the same direction. The patterns of lamination are as follows:

i. Pattern 2 consists of one sheet of polyester fabric, two sheets of carbon-aramid fabric, one sheet of polyester, two sheets of carbon-aramid, one sheet of polyester, two sheets of carbon-aramid, and one sheet of polyester (1-2-1-2-1-2-1).

ii. Pattern 1 consists of one sheet of polyester fabric, two pieces of carbon-aramid fabric, one sheet of polyester, two pieces of carbon-aramid, and one sheet of polyester (1-2$1-2-1)$.

The sizes of sewing thread used for combining the fabric were 20/2 and 40/2. There were two types of directions for the reinforcement seam: vertical-horizontal and diagonal. Meanwhile, the lengths of the reinforcement seams were $25 \mathrm{~mm}$ and $15 \mathrm{~mm}$. Table 1 shows the combinations of materials used in the research.

Table 1. Material combinations.

\begin{tabular}{|c|c|c|c|c|c|c|c|}
\hline $\begin{array}{c}\text { Experi } \\
\text { ment } \\
\text { Number }\end{array}$ & $\begin{array}{c}\text { Number } \\
\text { of } \\
\text { Laminat } \\
\text { ions (A) }\end{array}$ & $\begin{array}{c}\text { Woven } \\
\text { Construc } \\
\text { tion (B) }\end{array}$ & $\begin{array}{c}\text { Direction } \\
\text { of } \\
\text { Laminati } \\
\text { on } \\
\text { Arrange } \\
\text { ment (C) }\end{array}$ & $\begin{array}{c}\text { Pattern } \\
\text { of } \\
\text { Laminati } \\
\text { on } \\
\text { Arrange } \\
\text { ment (D) }\end{array}$ & $\begin{array}{c}\text { Size of } \\
\text { Reinforce } \\
\text { ment } \\
\text { Thread } \\
\text { (E) }\end{array}$ & $\begin{array}{c}\text { Direction } \\
\text { of } \\
\text { Reinforce } \\
\text { ment } \\
\text { Seam (F) }\end{array}$ & $\begin{array}{l}\text { Length of } \\
\text { Reinforce } \\
\text { ment } \\
\text { Seam (G) }\end{array}$ \\
\hline 1 & 7 & Plain & Parallel & $\begin{array}{c}1-2-1-2- \\
1-2-1\end{array}$ & $20 / 2$ & $\begin{array}{l}\text { Vertical- } \\
\text { horizontal }\end{array}$ & $25 \mathrm{~mm}$ \\
\hline 2 & 7 & Plain & Parallel & $1-2-1-2-1$ & $40 / 2$ & Diagonal & $15 \mathrm{~mm}$ \\
\hline 3 & 7 & Twill & $90^{\circ}$ & $\begin{array}{c}1-2-1-2- \\
1-2-1\end{array}$ & $20 / 2$ & Diagonal & $15 \mathrm{~mm}$ \\
\hline 4 & 7 & Twill & $90^{\circ}$ & $1-2-1-2-1$ & $40 / 2$ & $\begin{array}{l}\text { Vertical- } \\
\text { horizontal }\end{array}$ & $25 \mathrm{~mm}$ \\
\hline 5 & 10 & Plain & $90^{\circ}$ & $\begin{array}{c}1-2-1-2- \\
1-2-1\end{array}$ & $40 / 2$ & $\begin{array}{l}\text { Vertical- } \\
\text { horizontal }\end{array}$ & $15 \mathrm{~mm}$ \\
\hline 6 & 10 & Plain & $90^{\circ}$ & $1-2-1-2-1$ & $20 / 2$ & Diagonal & $25 \mathrm{~mm}$ \\
\hline 7 & 10 & Twill & Parallel & $\begin{array}{c}1-2-1-2- \\
1-2-1\end{array}$ & $40 / 2$ & Diagonal & $25 \mathrm{~mm}$ \\
\hline 8 & 10 & Twill & Parallel & $1-2-1-2-1$ & $20 / 2$ & $\begin{array}{l}\text { Vertical- } \\
\text { horizontal }\end{array}$ & $15 \mathrm{~mm}$ \\
\hline
\end{tabular}

The direction and distance of the reinforcing seam of each sheet of laminating constituent are as follows. Figure 1(a): the direction of the stitches forms a diagonal pattern with a length of $25 \mathrm{~mm}$ between stitches. Figure 1(b): the direction of the stitches forms a diagonal pattern with a length between the stitches of $15 \mathrm{~mm}$. Figure 1(c): the direction of the stitches forms a vertical-horizontal pattern with a length size of $25 \mathrm{~mm}$. Figure 1(d): the direction of the stitches forms a vertical-horizontal pattern with a length of $15 \mathrm{~mm}$. 


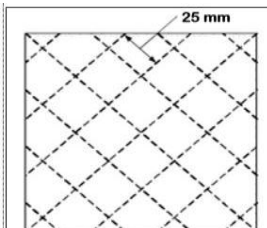

(a)

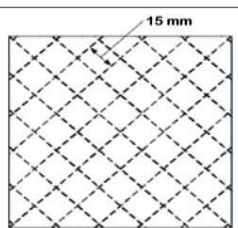

(b)

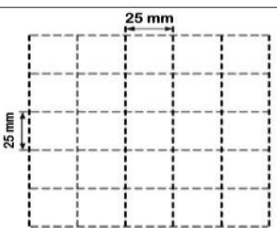

(c)

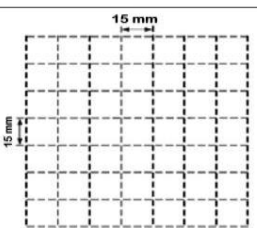

(d)

Fig. 1. Direction and length of reinforcement seams.

\subsection{Quasi-static impact test}

To determine the ability of soft body armor material, a quasi-static impact test was performed by Bull et al. [19] and Yahaya et al. [20]. The testing technique was carried out as follows:

i. The arranged material of the soft body armor was placed on the container of the material wedge with a clamp (bolt and screw), as shown in Figure 2(a), so the material does not move during the test.

ii. The soft body armor material was pressed with a tool of a shape similar to a $9 \mathrm{~mm}$ caliber bullet, as in Figure 2(b).

iii. Testing of the soft body armor base material using a UTM was done by pushing the pressuring material on the unit (UTM) toward the soft body armor material at the bottom of the pressing device until it showed the highest quasi-static impact value, as in Figure 2(c).

iv. Testing was done 12 times on each panel bundle with different positions on each, where the aim to test the strength of the panel bundles is based on the quasi-static impact test. Each point that has been marked in Figure 2(d) will be subjected to testing around three times with different pressing positions. The total number of tests against both panel bundles was 24, as seen in one of the panel bundles in Figure 2(d).

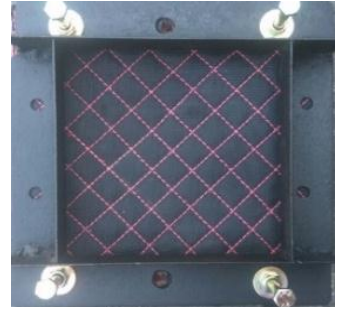

(a)

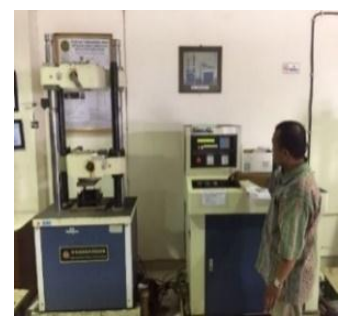

(c)

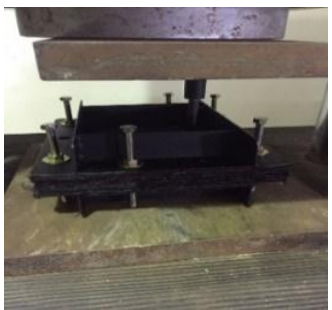

(b)

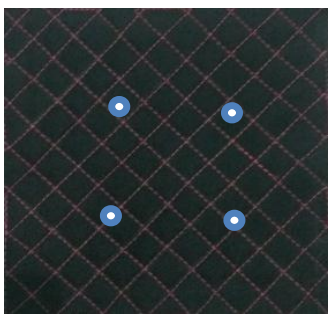

(d)

Fig. 2. Quasi-static impact tests. 


\section{Result and discussions}

\subsection{Normality and homogeneity test}

A normality and homogeneity test was done to identify the data obtained from the research results; in this case, it was used to determine whether the test data of the quasi-static impact test were normally distributed and whether the data obtained are homogeneous. This normality and homogeneity test was done using Minitab software version 18 . The normality test results obtained a probability value of $0.065(P>0.05)$, which means the research data are normally distributed. Then, the Bartlett homogeneity test results obtained a probability value of $0.957(P>0.05)$, which means the data are homogeneous.

\subsection{Analysis of variance (ANOVA)}

An analysis of variance (ANOVA) test was used to identify the impact of each factor on the soft body armor panel. This analysis was done using a $5 \%$ significance level and $95 \%$ confidence level. The result of the ANOVA can be seen in Table 2.

Table 2. Analysis of variance results.

\begin{tabular}{|c|c|c|c|c|c|c|}
\hline Source & DF & Adj SS & Adj MS & F Value & $\mathbf{P}$ & $\begin{array}{c}\text { Contribution } \\
\text { Rate } \%\end{array}$ \\
\hline A & 1 & $\begin{array}{c}3945605 \\
381\end{array}$ & $\begin{array}{c}3945605 \\
381\end{array}$ & 44.43 & 0.000 & 31.23 \\
\hline B & 1 & $\begin{array}{c}3028486 \\
267\end{array}$ & $\begin{array}{c}3028486 \\
267\end{array}$ & 34.1 & 0.000 & 23.80 \\
\hline $\mathrm{C}$ & 1 & 623851135 & $\begin{array}{c}623851 \\
135\end{array}$ & 7.03 & 0.017 & 4.33 \\
\hline D & 1 & $\begin{array}{c}1285329 \\
188\end{array}$ & $\begin{array}{c}1285329 \\
188\end{array}$ & 14.47 & 0.002 & 9.69 \\
\hline $\mathrm{E}$ & 1 & $\begin{array}{c}1170137 \\
824\end{array}$ & $\begin{array}{c}1170137 \\
824\end{array}$ & 13.18 & 0.002 & 8.76 \\
\hline $\mathrm{F}$ & 1 & 383285964 & $\begin{array}{c}383285 \\
964\end{array}$ & 4.32 & 0.054 & 2.38 \\
\hline G & 1 & 492969696 & $\begin{array}{c}492969 \\
696 \\
\end{array}$ & 5.55 & 0.032 & 3.27 \\
\hline Error & 16 & $\begin{array}{c}1420795 \\
773\end{array}$ & 88799736 & & & 16.54 \\
\hline Total & 23 & $\begin{array}{c}12350461 \\
228\end{array}$ & & & & 100 \\
\hline
\end{tabular}

Based on the results of the ANOVA test, which used Minitab software version 18 in Table 2, six factors that significantly influence the strength of the soft body armor panel were obtained. These factors are factor A (number of laminations), factor B (woven construction), factor $\mathrm{C}$ (direction of lamination arrangement), factor $\mathrm{D}$ (pattern of lamination), factor $\mathrm{E}$ (size of reinforcement thread), and factor $\mathrm{G}$ (distance of reinforcement seams) with a probability value greater than $0.05(P<0.05)$ or $\mathrm{F}$ value $\geq \mathrm{F}$ table $(\mathrm{F}$ value $\geq$ 4.49). The contribution rate value has the largest contribution percentage at $31.23 \%$, indicating that factor $\mathrm{A}$ has the greatest contribution to the strength of the soft body armor panel. 


\subsection{Quasi-static impact test}

Based on the loss function approach of the Taguchi method, the quasi-static impact test used a type of quality characteristic measurement to achieve the target, that is, higher is better to find the maximum strength to hold the load. In this test, the greater the responded value, the better the material quality. In Figure 3 shows the result of test using Universal Testing Machine (UTM). If the value of the signal-to-noise ratio (SNR) is higher, then the contribution of each controlled factor in the experiment is better. The SNR value can be seen in Table 3, as follows:

$$
S N R_{H B}=-10 \log \left[1 / r \sum_{i=1}^{r} 1 / y i^{2}\right]
$$

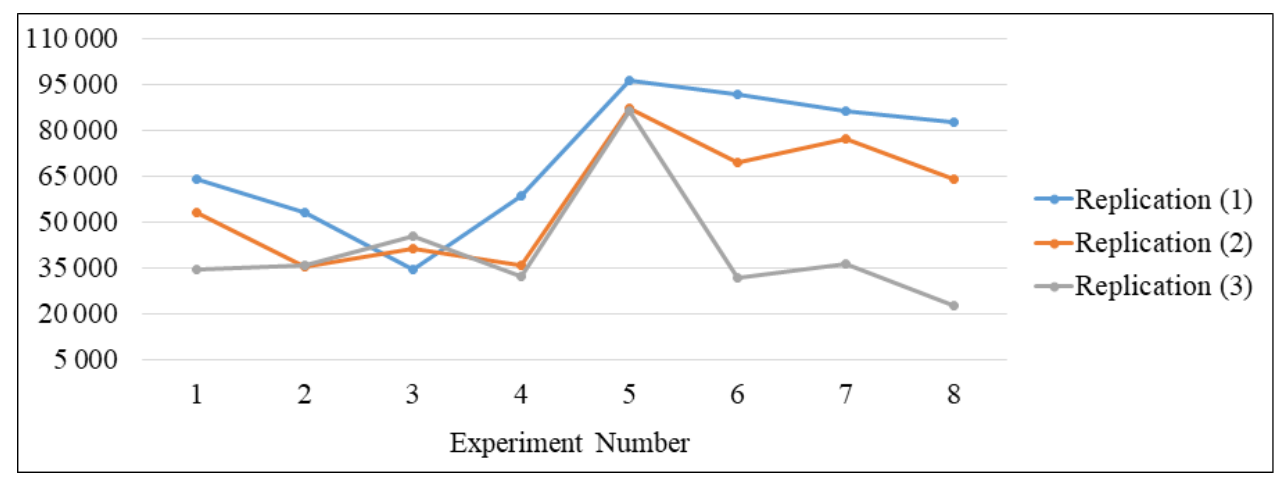

Fig. 3. Quasi-static impact tests result.

Table 3. SNR values with high is better characteristic.

\begin{tabular}{|c|c|c|c|c|c|c|c|c|c|c|c|c|}
\hline \multirow{2}{*}{$\begin{array}{l}\text { Experiment } \\
\text { Number }\end{array}$} & \multicolumn{7}{|c|}{ Factors } & \multicolumn{3}{|c|}{ Replication (N) } & \multirow{2}{*}{$\begin{array}{c}\mathrm{S} / \mathrm{N} \\
\text { (Ratio) }\end{array}$} & \multirow{2}{*}{ Mean } \\
\hline & $\mathbf{A}$ & B & C & D & $\mathbf{E}$ & $\mathbf{F}$ & G & 1 & 2 & 3 & & \\
\hline 1 & 1 & 1 & 1 & 1 & 1 & 1 & 1 & $\begin{array}{c}64 \\
075.129\end{array}$ & $\begin{array}{c}53 \\
182.444\end{array}$ & $\begin{array}{c}34 \\
650.120\end{array}$ & 93.2178 & $\begin{array}{c}50 \\
635.9\end{array}$ \\
\hline 2 & 1 & 1 & 1 & 2 & 2 & 2 & 2 & $\begin{array}{c}53 \\
262.296\end{array}$ & $\begin{array}{c}35 \\
207.028\end{array}$ & $\begin{array}{c}35 \\
989.896\end{array}$ & 91.9127 & $\begin{array}{c}41 \\
486.4\end{array}$ \\
\hline 3 & 1 & 2 & 2 & 1 & 1 & 2 & 2 & $\begin{array}{c}34 \\
650.120\end{array}$ & $\begin{array}{c}41 \\
450.967\end{array}$ & $\begin{array}{c}45 \\
207.028\end{array}$ & 91.9740 & $\begin{array}{c}40 \\
436.0\end{array}$ \\
\hline 4 & 1 & 2 & 2 & 2 & 2 & 1 & 1 & $\begin{array}{c}58 \\
369.097\end{array}$ & $\begin{array}{c}35 \\
861.915\end{array}$ & $\begin{array}{c}31 \\
967.577\end{array}$ & 91.6545 & $\begin{array}{c}42 \\
066.2\end{array}$ \\
\hline 5 & 2 & 1 & 2 & 1 & 2 & 1 & 2 & $\begin{array}{c}96 \\
144.688\end{array}$ & $\begin{array}{c}87 \\
300.188\end{array}$ & $\begin{array}{c}86 \\
409.340\end{array}$ & 99.0504 & $\begin{array}{c}89 \\
951.4\end{array}$ \\
\hline 6 & 2 & 1 & 2 & 2 & 1 & 2 & 1 & $\begin{array}{c}91 \\
657.449\end{array}$ & $\begin{array}{c}69 \\
665.781\end{array}$ & $\begin{array}{c}31 \\
655.450\end{array}$ & 93.5556 & $\begin{array}{c}64 \\
326.2\end{array}$ \\
\hline
\end{tabular}

Table 3. Continued on next page 
Table 3. Continued

\begin{tabular}{|c|c|c|c|c|c|c|c|c|c|c|c|c|}
\hline \multirow{2}{*}{$\begin{array}{l}\text { Experiment } \\
\text { Number }\end{array}$} & \multicolumn{7}{|c|}{ Factors } & \multicolumn{3}{|c|}{ Replication (N) } & \multirow{2}{*}{$\begin{array}{c}\mathrm{S} / \mathrm{N} \\
\text { (Ratio) }\end{array}$} & \multirow{2}{*}{ Mean } \\
\hline & $\mathbf{A}$ & B & C & D & $\mathbf{E}$ & $\mathbf{F}$ & G & 1 & 2 & 3 & & \\
\hline 7 & 2 & 2 & 1 & 1 & 2 & 2 & 1 & $\begin{array}{c}86 \\
409.340\end{array}$ & $\begin{array}{c}77 \\
027.271\end{array}$ & $\begin{array}{c}36 \\
149.689\end{array}$ & 94.4867 & $\begin{array}{c}66 \\
528.8\end{array}$ \\
\hline 8 & 2 & 2 & 1 & 2 & 1 & 1 & 2 & $\begin{array}{c}82 \\
611.984\end{array}$ & $\begin{array}{c}63 \\
955.215\end{array}$ & $\begin{array}{c}22 \\
611.984\end{array}$ & 91.0665 & $\begin{array}{c}56 \\
393.1\end{array}$ \\
\hline
\end{tabular}

Table 3 shows that the highest SNR and highest mean value are found in the fifth experiment, where the SNR is 99.0504 and the highest mean is 89 951.4. Then, from the SNR resulting value, the ratio will be used to determine the optimal value from the combination of each factor and level. The calculation of the combination of the optimal value of each factor and level can be seen in Table 4 below:

Table 4. Effect value, difference, and rank of each factor.

\begin{tabular}{|c|c|c|c|c|c|c|c|}
\hline \multirow{2}{*}{ Level } & \multicolumn{7}{|c|}{ Factors } \\
\cline { 2 - 8 } & A & B & C & D & E & F & G \\
\hline 1 & 92.19 & 94.43 & 92.67 & 94.68 & 92.45 & 93.75 & 93.23 \\
\hline 2 & 94.54 & 92.30 & 94.06 & 92.05 & 94.28 & 92.98 & 93.50 \\
\hline Delta & 2.35 & 2.14 & 1.39 & 2.63 & 1.82 & 0.77 & 0.27 \\
\hline Rank & 2 & 3 & 5 & 1 & 4 & 6 & 7 \\
\hline
\end{tabular}

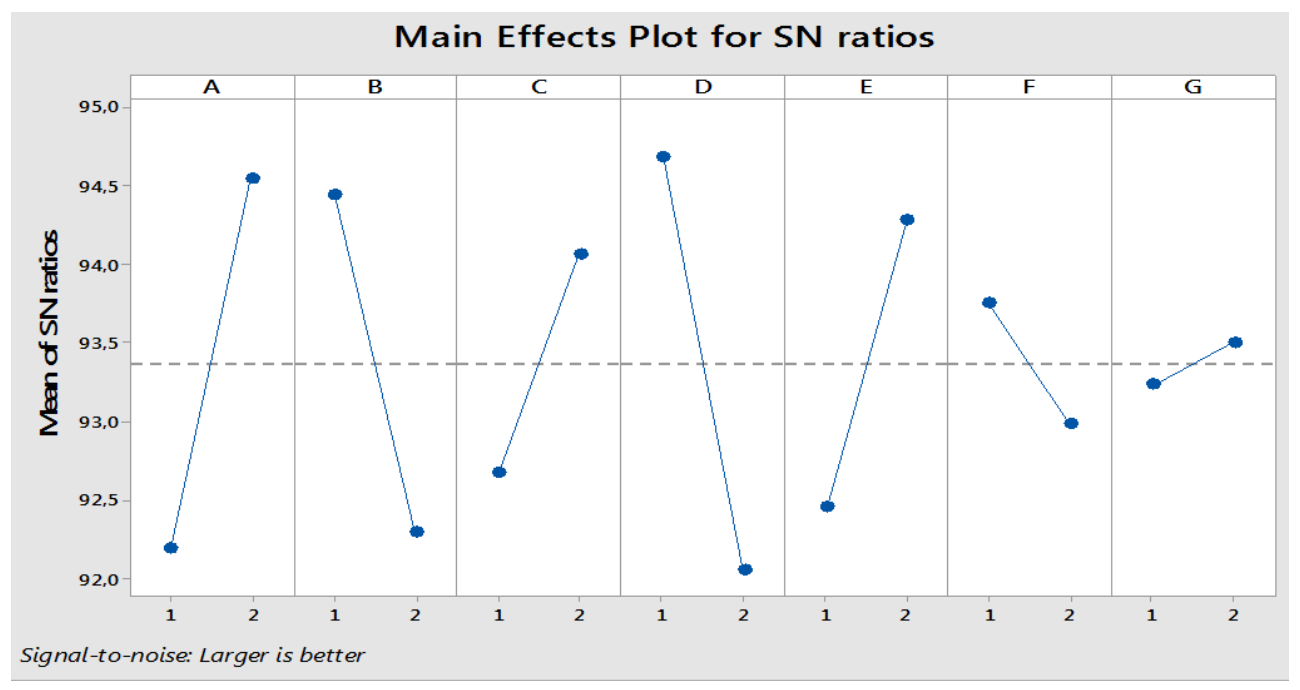

Fig. 4. Effect value, difference, and rank of each factor. 
Based on the calculations in Table 4, the optimum combination of factors and levels for the soft body armor panel is as follows: factor D level 1 (lamination arrangement pattern is 1-2-1-2-1-2-1) with a value of 94.68, factor A level 2 (lamination amount is 10) with a value of 94.54, factor B level 1 (woven construction is plain) with a value of 94.43 , factor $\mathrm{E}$ level 2 (size of reinforcement thread is 40/20) with a value of 94.28, factor C level 2 (direction of lamination arrangement is $90^{\circ}$ ) with a value of 94.06, factor $\mathrm{F}$ level 1 (direction of reinforcement is vertical-horizontal) with a value is 93.75, and factor $\mathrm{G}$ level 2 (length of seam reinforcement is $15 \mathrm{~mm}$ ) with a value of 93.50 .

Based on the result of SNR processing and the optimum combination of factors and levels, the calculation of the average value of the quasi-statistical results for the soft body armor panel is shown in Table 5.

Table 5. Average value of the quasi-static impact test results for the soft body armor panel.

\begin{tabular}{|c|c|c|c|}
\hline \multicolumn{3}{|c|}{ Impact Test (N) } & \multirow{2}{*}{ Average (N) } \\
\cline { 1 - 3 } $\mathbf{1}$ & $\mathbf{2}$ & $\mathbf{3}$ & \\
\hline 74504.2522 & 62148.3278 & 47127.16471 & 61259.91 \\
\hline
\end{tabular}

Table 5 shows that the average value of the quasi-static impact test on the soft body armor panel, resulting in $61259.91 \mathrm{~N}$. The technical data of PT. Pindad can be explained that for (MU1-JHP) ammunition of $9 \mathrm{~mm} \times 19 \mathrm{~mm}$ in diameter with gas pressure (pressure applied to the projectile inside the bullet) of maximum $2600 \mathrm{~kg} \mathrm{~cm}^{-2}$ or $25497.29 \mathrm{~N}$ in Newton units. If the shooting range with (MU1-JHP) ammunition of $9 \mathrm{~mm} \times 19 \mathrm{~mm}$ in diameter against the soft body armor panel is $5 \mathrm{~m}$, the results show that the soft body armor panel is expected to withstand the projectile's strike.

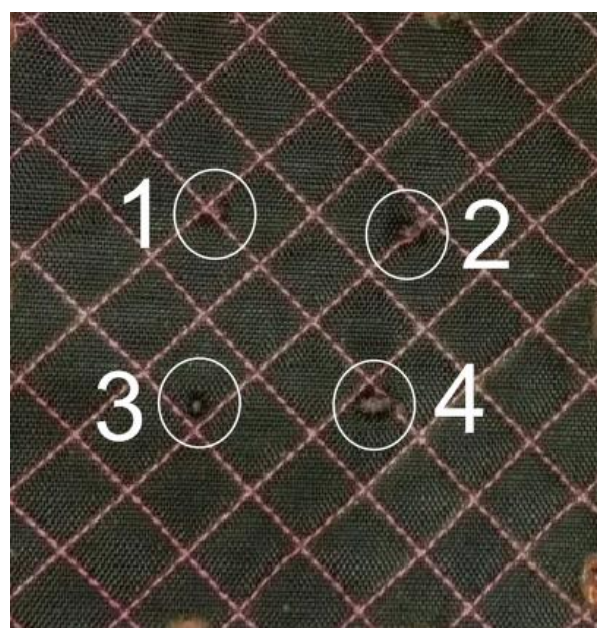

Fig. 5. Quasi-static impact test result on soft body armor panel.

\section{Conclusion}

The quasi-static impact test on the soft body armor panel composed of a carbon-aramid and polyester base was obtained based on the optimum composition: factor D with a 1-2-1-2-12-1 lamination arrangement pattern, factor $\mathrm{A}$ with a total of 10 laminations, factor $\mathrm{B}$ with a plain woven construction, factor $E$ with a $40 / 20$ reinforcement thread size, factor $C$ with a 
lamination direction of $90^{\circ}$, factor $\mathrm{F}$ with a vertical-horizontal reinforcement seam direction, and factor $\mathrm{G}$ with a stitch length of $15 \mathrm{~mm}$. The optimum composition of the soft body armor panel with a quasi-static impact test obtained an average value of $61259.91 \mathrm{~N}$. In addition, if the soft body armor were to undergo a shooting, then a bundle of soft body armor panels would be expected to withstand a projectile strike of (MU1-JHP) ammunition of $9 \mathrm{~mm} \times 19 \mathrm{~mm}$ in diameter. For further research, it is recommended to examine the potential of the user's body to hold the ballistic energy generated from projectile strikes, so ballistic testing is required.

\section{References}

1. W. Qiushi, S. Runjun, T. Xiao, Y. Mu, F. Yan. Results Phys, 6:554-560(2016). https://www.sciencedirect.com/science/article/pii/S2211379716301279

2. S.L. Phoenix, U. Heisserer, H. Werff, M. van der Jagt. Fibers, 5,8:1-41(2017). https://www.researchgate.net/publication/314155296_Modeling_and Experiments on Ballistic_Impact into_UHMWPE_Yarns_Using_Flat and_Saddle-Nosed_Projectiles

3. M.A. Abtew, F. Boussu, P. Bruniaux, C. Loghin, I. Cristian, C. Yan, et al. Compos. Part A Appl. Sci. Manuf., 109:517-537(2018). https://www.sciencedirect.com/science/article/pii/S1359835X18300885

4. G. Nilakantan, S. Nutt. Def. Technol., 14,3:165-178(2018). https://www.sciencedirect.com/science/article/pii/S2214914717302404

5. M.H. Struszczyk, D. Zielińska, M. Miklas, G. Grabowska, J. Błaszczyk, I. KucińskaKról, et al. Fibres Text. East. Eur., 25,2:88-92 (2017). http://www.fibtex.lodz.pl/2017/2/88.pdf.

6. A.R.A. Hani, N.S. Azman, R. Ahmad, M. Mariatti, M.N. Roslan, N. Marsi. 2nd International Conference on Green Design and Manufacture 2016 (IConGDM 2016) (Phuket, Thailand 2016). MATEC Web of Conferences, 78,01048(2016). https://www.matecconferences.org/articles/matecconf/abs/2016/41/matecconf icongd m2016 01048/matecconf icongdm2016 01048.html

7. Z. Yi, C. Xiaogang, G. Wells. Composites. Part B Eng., 62:198-204(2014). https://www.sciencedirect.com/science/article/pii/S1359836814000997

8. A.E. Kisler-Rao. JASTEE, 6,1:3-20(2015). http://www.unitedstatesbd.com/images/unitedstatesbdcom/bizcategories/2961/files/JA STEE $2015 \quad 6 \quad 1$ 1.pdf.

9. A. Laha, A. Majumdar, I. Biswas, S.K. Verma, D. Bhattacharjee. Role of fabric geometry in ballistic performance of flexible armour panels. 11th International Symposium on Plasticity and Impact Mechanics (New Delhi, India 2016). Procedia Engineering, 173:747-754 (2017). https://www.sciencedirect.com/science/article/pii/S1877705816344629

10. Zubaidi, M. Moeliono, S. Santoso. Arena Tekst., 24,2:60-67(2009). [in Bahasa Indonesia]. http://lib.kemenperin.go.id/neo/download artikel.php?id=9.

11. Y. Yanfei, C. Xiaogang. Compos. Part B Eng., 98:250-259(2016). https://www.sciencedirect.com/science/article/pii/S1359836816305236

12. I.K. Yilmazcoban, S. Doner. Acta Phys. Pol. A. 130,1:342-346(2016). http://przyrbwn.icm.edu.pl/APP/PDF/130/a130z1p092.pdf.

13. D. Dimeski, G. Bogoeva-Gaceva, V. Srebrenkoska. Ballistic properties of polyethylene composites based on bidirectional and undirectional fibers. Paper presented in Simpozijumu Savremene tehnologije i privredni razvoj (Lescovac, Serbia 2011). http://www.tf.ni.ac.rs/casopis-arhiva/zbornik20/21.pdf. 
14. H. Qianyun, C. Saisai, W. Yunpeng, X. Shouhu, W. Pengfei, G. Xinglong. Compos. Part A Appl. Sci. Manuf., 106:82-90(2018). https://www.sciencedirect.com/science/article/pii/S1359835X17304530

15. H. Purnomo, H. Widananto, J. Sulistio. The optimization of soft body armor materials made from carbon-aramid fiber using the Taguchi method. ICETIA (Surakarta, Indonesia, 2017). AIP Conference Proceedings, 1977,020003(2018). https://aip.scitation.org/doi/10.1063/1.5042859

16. C. Târcolea, A.S. Paris, D. Sylvan. Loss functions and Taguchi theory. Paper presented in The International Conference Differential Geometry-Dynamical System (Bucharest, Rumania 2013). http://www.mathem.pub.ro/proc/bsgp-21/K21-ta-846.pdf.

17. I. Kotcioglu, M.N. Khalaji, A. Cansiz. Appl. Therm. Eng., 132:637-650(2018). https://www.sciencedirect.com/science/article/pii/S1359431117339248

18. T. Yu, L. Shaoming, L. Guoyuan, Y.Z. Zhou, C. Ruisen, H. Yilong, et al. Microelectronics Journal, 73:18-23(2018).

https://www.sciencedirect.com/science/article/abs/pii/S0026269217304019

19. D.J. Bull, S.M. Spearing, I. Sinclair. Compos. Part A Appl. Sci. Manuf., 74:3846(2015). https://kundoc.com/pdf-investigation-of-the-response-to-low-velocityimpact-and-quasi-static-indentatio.html

20. R. Yahaya, S.M. Sapuan, M. Jawaid, Z. Leman, E.S. Zainudin. Mater. Des., 63:775782(2014). https://www.sciencedirect.com/science/article/pii/S0261306914005378 